University of Wollongong

Research Online

Faculty of Business - Papers (Archive)

Faculty of Business and Law

$1-1-2014$

Do low-skilled migrants contribute more to home country income? Evidence from South Asia

Arusha V. Cooray

University of Wollongong, arusha@uow.edu.au

Follow this and additional works at: https://ro.uow.edu.au/buspapers

Part of the Business Commons

Research Online is the open access institutional repository for the University of Wollongong. For further information contact the UOW Library: research-pubs@uow.edu.au 


\title{
Do low-skilled migrants contribute more to home country income? Evidence from South Asia
}

\begin{abstract}
A recursive system is employed to investigate the indirect effect of out-migration on gross domestic product (GDP) through remittances in South Asia, namely Bangladesh, India, Nepal, Pakistan, and Sri Lanka. Out-migration is further disaggregated by skill level and country of destination (Middle East and other), and their effects on GDP through remittances are examined. The results suggest that migration and remittances have an important significant effect on the GDP of the countries under study. Of the skill categories, the unskilled category has the largest robust indirect effect on GDP. The effects of migration on GDP by country of destination suggest that migration to the Middle East has a robust and significant impact on GDP. There is some evidence of a combination between the altruistic and self-interested motives of migrants' to remit.
\end{abstract}

\section{Keywords}

south, evidence, income, country, home, more, contribute, asia, migrants, do, skilled, low

\section{Disciplines \\ Business}

\section{Publication Details}

Cooray, A. (2014). Do low-skilled migrants contribute more to home country income? Evidence from South Asia. BE Journal of Economic Analysis and Policy, 14 (3), 1185-1212. 


\title{
Topics
}

\section{Arusha Cooray* Do Low-Skilled Migrants Contribute More to Home Country Income? Evidence from South Asia}

\begin{abstract}
A recursive system is employed to investigate the indirect effect of out-migration on gross domestic product (GDP) through remittances in South Asia, namely Bangladesh, India, Nepal, Pakistan, and Sri Lanka. Out-migration is further disaggregated by skill level and country of destination (Middle East and other), and their effects on GDP through remittances are examined. The results suggest that migration and remittances have an important significant effect on the GDP of the countries under study. Of the skill categories, the unskilled category has the largest robust indirect effect on GDP. The effects of migration on GDP by country of destination suggest that migration to the Middle East has a robust and significant impact on GDP. There is some evidence of a combination between the altruistic and self-interested motives of migrants' to remit.
\end{abstract}

Keywords: migration, South Asia, skill level, remittances, Middle East

*Corresponding author: Arusha Cooray, School of Economics, University of Wollongong, Northfields Ave, Wollongong, NSW 2522, Australia, E-mail: arusha@uow.edu.au

\section{Introduction}

The stock of out-migrants from South Asia currently stands at 12.2 million or $0.7 \%$ of the population compared to 215.8 million or $3.2 \%$ for the world (Ratha, Mohapatra, and Silwal 2011). The benefits of migration accrued in the form of remittances comprise the largest source of external funding to South Asia, with receipts having increased phenomenally over the 2000 to 2010 period. Remittance inflows to Pakistan have increased eightfold from US\$1 billion in 2000 to US $\$ 8$ billion in 2010 ; Bangladesh, from US $\$ 1.9$ to US $\$ 9.9$ billion; India from US $\$ 12.9$ to US $\$ 53$ billion; Nepal, from US $\$ 111$ million to US\$ 3.5 billion; and Sri Lanka, from US $\$ 1.2$ billion to 4.1 billion (World Bank 2011). India is the 
largest remittance-receiving country in the world accounting for $73 \%$ of the flow into South Asia, with Bangladesh seventh and Pakistan eleventh (World Bank 2011).

Labour migration from South Asia has primarily been temporary migration to the Middle East and Gulf Nations (see Table 1). In 2010, labour migration from Bangladesh to the Middle East and Gulf (ME hereafter) stood at $84 \%$ of total migration. The figures for the rest of the countries were $40 \%$ for India, $93 \%$ for Sri Lanka in 2009, and 97\% for Pakistan in 2004. Remittances from the Middle East accounted for $71 \%$ of total remittances in Bangladesh, 60\% in Sri Lanka, $58 \%$ in Pakistan, and 22\% in India (see Table 8 for data sources). The push factors for labour migration include poverty, unemployment, and networks (IOM 2000). The pull factors are the attraction of higher wages and the demand for labour from the ME. Unskilled labour makes up over 50\% of the labour flows from these economies to the ME.

Table 1: Migration and remittance totals and Middle East

\begin{tabular}{|c|c|c|c|c|c|c|c|}
\hline Year & Country & $\begin{array}{r}\begin{array}{r}\text { Migration } \\
\text { total }\end{array} \\
\text { (number) }\end{array}$ & $\begin{array}{r}\begin{array}{r}\text { Migration } \\
\text { to ME }\end{array} \\
\text { (number) }\end{array}$ & $\begin{array}{r}\begin{array}{r}\text { Migration } \\
\text { to } \mathrm{ME}\end{array} \\
\text { (\% of total) }\end{array}$ & $\begin{array}{r}\begin{array}{r}\text { Remittances } \\
\text { total }\end{array} \\
\text { (USS mn) }\end{array}$ & $\begin{array}{r}\begin{array}{r}\text { Remlttances } \\
\text { from ME }\end{array} \\
\text { (USS mn) }\end{array}$ & $\begin{array}{r}\begin{array}{r}\text { Remittances } \\
\text { from ME }\end{array} \\
\text { (\% of total) }\end{array}$ \\
\hline \multirow[t]{5}{*}{1980} & Bangladesh & 30,073 & 27,756 & 92.3 & 301 & 232 & 77 \\
\hline & India & 236,200 & 218,248 & 92.4 & 2,757 & 2,120 & 77 \\
\hline & Pakistan & 129,800 & 126,165 & 97.2 & 710 & 426 & 60 \\
\hline & Sri Lanka & 7,600 & - & - & 152 & 61 & 40 \\
\hline & Nepal & - & - & - & - & - & \\
\hline \multirow[t]{5}{*}{1990} & Bangladesh & 103,814 & 98,436 & 94.8 & 782 & 547 & 70 \\
\hline & India & 139,861 & 134,266 & 96.0 & 2,384 & 1,471 & 62 \\
\hline & Pakistan & 113,781 & 112,643 & 99.0 & 648 & 298 & 46 \\
\hline & Srl Lanka & 42,625 & 40,664 & 95.4 & 401 & 217 & 54 \\
\hline & Nepal & 83,020 & - & - & - & - & 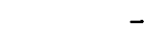 \\
\hline \multirow[t]{5}{*}{2000} & Bangladesh & 222,686 & 191,584 & 86.0 & 1,955 & 1,514 & 77 \\
\hline & India & 243,182 & 177,165 & 72.9 & 12,883 & 4,110 & 32 \\
\hline & Pakistan & 107,733 & 104,463 & 97.0 & 984 & 682 & 69 \\
\hline & Sri Lanka & 182,188 & 176,364 & 96.8 & 1,166 & 735 & 63 \\
\hline & Nepal & 35,543 & - & - & 111 & - & \\
\hline \multirow[t]{5}{*}{2010} & Bangladesh & 383,150 & 320,898 & 83.8 & 9,983 & 7,047 & 7 \\
\hline & India ${ }^{a}$ & 610,272 & 244,109 & 40.0 & 49,468 & 10,882 & 22 \\
\hline & Pakistan & 331,254 & - & - & 8,905 & 5,194 & 58 \\
\hline & Sri Lanka ${ }^{\mathrm{a}}$ & 247,119 & 230,262 & 93.2 & 3,363 & 2,014 & 60 \\
\hline & Nepal $^{b}$ & 269,494 & - & - & 3,507 & - & - \\
\hline
\end{tabular}

Notes: ${ }^{a}$ For India and Sri Lanka data are for $2009 .{ }^{b}$ For Nepal migration data are for 2008. Data Sources provided in Table 8. 
The significance of out-migration and remittances for South Asia gives rise to a number of questions. How does labour migration contribute to the gross domestic product (GDP) of these economies? How does labour migration to the ME and other destinations contribute to the GDP of these economies? How does the skill level of the migrants influence remittance flows and consequently GDP? What are the implications of these flows for these countries and how sustainable are these flows? Answers to these questions are of utmost importance for identifying the role of migration in the growth trajectory of South Asia and for implementing appropriate policies for migrants and their families.

Notwithstanding the rapidly growing literature on migration, much of the emphasis of studies on migration has revolved around the brain drain argument (see Docquier, Lohest, and Marfouk 2007; Docquier, Lowell, and Marfouk 2009 for example). ${ }^{1}$ While there is a general consensus on the negative impacts of skilled migration on home country income, the effects of unskilled migration on home country income are less well understood. The objective of the present study therefore is to investigate the effects of migration on home country income, paying special attention to unskilled migration. The focus of the literature on remittances hitherto has been on the impact of remittances on various macro- and microeconomic variables including economic growth, poverty, income distribution, among other variables. Remittances into the developing economics have been found to have a number of positive effects at both the macro- and microeconomic levels. For example, they have served as insurance policies against risks associated with new production activities (Taylor 1999), helped low-income households to smoothen their consumption by reducing vulnerability to adverse domestic shocks (Yang and Choi 2007), increased the propensity to save (Adams 2002), and helped to reduce poverty (Adams and Page 2005). Remittances have even financed the construction of schools and clinics (see Martin, Martin, and Weil 2002 for a study of remittances sent to Mali from France; Orozco 2000). Remittances have also been found to reduce income inequality (Taylor 1999), promote economic growth (Mundaca 2009), promote financial sector development (Giuliano and Ruiz-Arranz 2009; Aggarwal, Demirguc-Kunt, and Martinez-Peria 2006), and reduce output volatility (Chami, Hakura, and Montiel 2009).

In addition to investigating the direct effects of remittances on GDP, the point of departure of the present study from the literature is as follows: First, the present study employs an integrated approach represented by a recursive equation system to investigate the indirect effects of out-migration on GDP through remittances. Second, given the significance of $M E$ remittances and migration for

1 See de Haas (2007) for a survey of the literature.

Brought to you by / Michigan State University Authenticated | 10.248.254.158

Download Date | 8/19/14 12:49 PM 
South Asia, the study distinguishes between the ME and other destination countries and investigates the effects of out-migration by destination on GDP through the mediating variable, remittances. Third, the study disaggregates the number of migrants by skill level and consequently examines the effects of the skill level of the migrant on GDP through migrants' remittances. There is relatively little evidence in the empirical literature on how the skill level of the migrants' affects home country income. ${ }^{2}$ Fourth, the effect of variables such as the rate of inflation, interest rate, and exchange rate on remittances are examined, in an attempt to capture the motive of migrants' to remit. Finally, the implications of the aforesaid aspects for policy are considered. The study covers Bangladesh, India, Pakistan, and Sri Lanka over the 1976-2010 period. Nepal is included only in the aggregate estimation due to the absence of data at a skill and destination disaggregated level.

The study is structured as follows. Section 2 discusses some region specific characteristics. Section 3 discusses the literature. Section 4 presents the empirical framework and data. Section 5 evaluates the empirical results. Section 6 discusses policy implications and concludes.

\section{Some region-specific characteristics}

All South Asian economies with the exception of the Maldives are net labour sending countries. With deregulation, the governments of South Asia have actively encouraged the migration of labour. Bangladesh for example introduced a special savings scheme in the form of Wage Earner Bonds to promote migrant savings. In Pakistan, local migrants remitting US\$2,500 per annum are entitled to duty-free imports of up to US\$700 per year and non-resident Pakistanis (NRPs) remitting a minimum of US $\$ 10,000$ through banking channels are entitled to duty-free imports of up to US $\$ 1,200$ from 2001. NRPs also have access to a merit-based quota system in all public professional colleges and universities, are able to participate in a lottery for land in public housing schemes at concessionary rates if they pay in foreign currency, and purchase shares in privatized companies. Sri Lanka has taken additional measures compared to the rest of South Asia to promote labour migration. Migrants are offered pre-

2 Docquier and Marfouk (2005) use data on the immigration structure by educational attainment and country of birth from all OECD receiving countries to estimates of emigration stocks and rates by educational attainment. The present study in contrast investigates the effect of the skill level of the migrant on home country remittances and GDP. 
departure loans to cover travel costs. Migrants and their families are granted free life insurance and can maintain non-resident foreign-currency accounts through which remittances can be transmitted. In India, certain states such as Kerala have set up Human Resource Corporations to encourage labour intensive exports. Migrants are also permitted to transfer capital between their home country and destination country free of government regulations (see Khatri 2007). ${ }^{3}$

More than $60 \%$ of the migrants from India, Sri Lanka, and Bangladesh and $54 \%$ of migrants from Pakistan are temporary unskilled workers (see Figure 1) who migrate largely to the ME and Gulf Nations (see Table 1). With the exception of Sri Lanka, the number of male migrants account for a larger share of migrants than the number of female migrants.

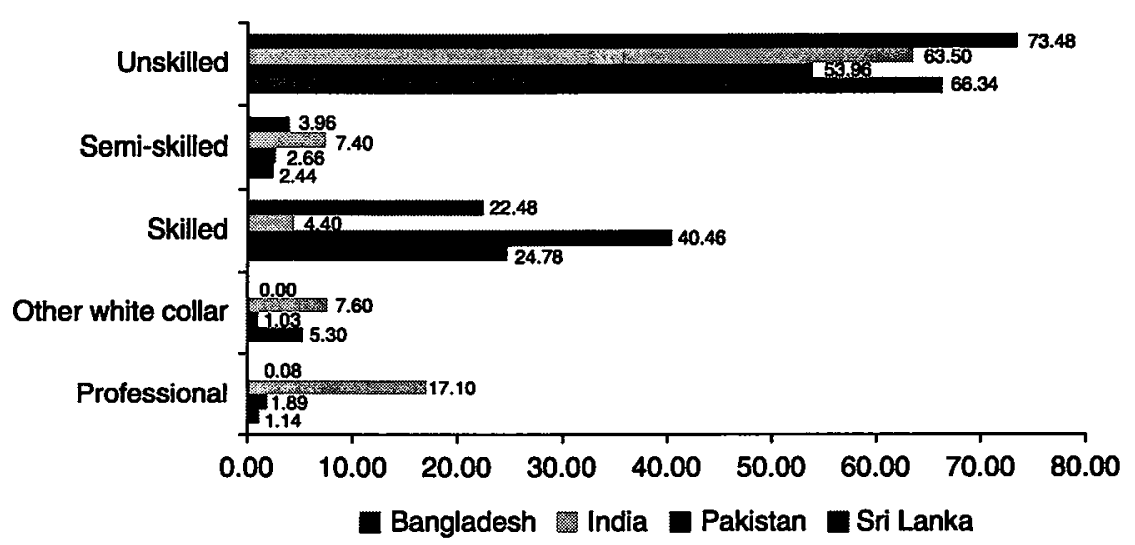

Figure 1: Skill composition of labour outflow from South Asia as of 2009

Note: Figures for India for 1998. Data sources provided in Table 8.

Lately however, migrants from India and Bangladesh have attempted to diversify their migration destinations due to geopolitical risks. During the Gulf war, many Indians were forced to return home and since the 1990s, the migration destinations of Indian migrants have diversified with approximately $60 \%$ of migrants departing to destinations such as North America, Europe, and South East Asia (Ratha, Mohapatra, and Silwal 2010). Despite this diversification, and with the exception of India, migration to the ME continues to play an important

3 See Khatri (2007) for a detailed discussion of measures taken and effects of labour migration in South Asia. 
role in South Asia's migration movements generating over 50\% of remittances for these economies (see Table 1). Evidence also reveals that the bulk of the remittances from the ME are sent by low and unskilled workers.

The significance of remittance flows is further illustrated by the fact that remittance flows as percentage of GDP exceed Overseas Development Aid (ODA) and Foreign Direct Investment (FDI) flows (Figure 2), acting as an important source of external financing to these countries.

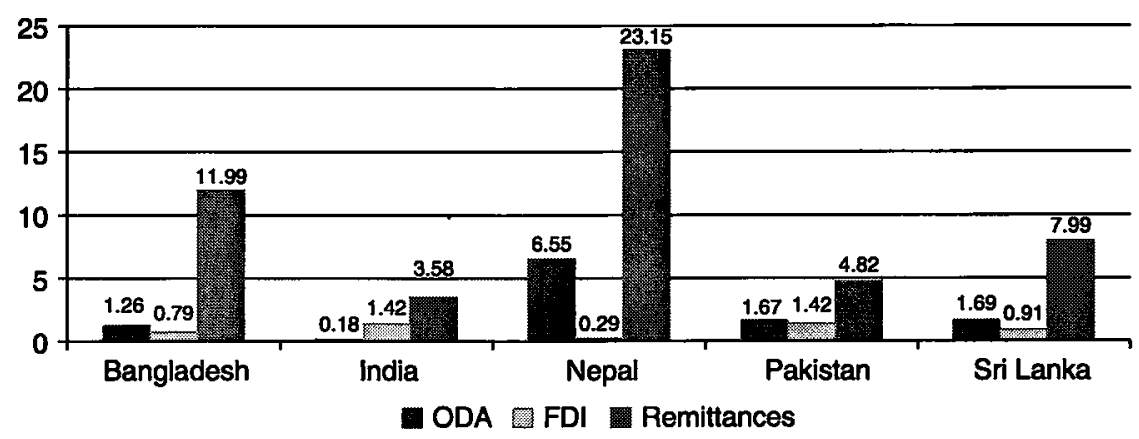

Figure 2: ODA, FDI, and remittance inflows as a \% of GDP Source: World Development Indicators (2011).

Table 2 reports descriptive statistics for the contribution made by remittances to the macroeconomy. The statistics suggest that remittance flows account for a significant share of GDP in these nations (see Table 2). Remittances have in addition contributed to easing the current account deficit of the balance of payments in these economies. In Sri Lanka for example, approximately $80 \%$ of the trade deficit was offset by remittance inflows (Arunatilake, Jayawardena, and Weerakoon 2011). The figures for 2010 show that in Bangladesh remittances account for slightly over $50 \%$ of export earnings and in Nepal remittance inflows account for $152 \%, 298 \%$, and $112 \%$ of export earnings, national savings, and investment respectively indicating the magnitude of the contribution made by remittances to these economies at the macroeconomic level.

Thus, in South Asia where labour migration is actively encouraged, remittances have acquired new significance. The effects of migration on the macroeconomy, particularly by skill level of the migrant, are less well understood. Accordingly, this study attempts to investigate the direct effects of migration on remittances, remittances on GDP, and indirect effects of migration on GDP for South Asia. 
Table 2: The contribution of remittances to the macroeconomy

\begin{tabular}{llrrrr}
\hline Year & Country & $\begin{array}{r}\text { Remittances } \\
\text { \% GDP }\end{array}$ & $\begin{array}{r}\text { Remittances \% } \\
\text { export earnings }\end{array}$ & $\begin{array}{r}\text { Remittances } \\
\text { \% savings }\end{array}$ & $\begin{array}{r}\text { Remittances \% } \\
\text { investment }\end{array}$ \\
\hline 1980 & Bangladesh & 1.66 & 30.27 & 11.52 & - \\
& India & 1.50 & 24.15 & 9.74 & 8.16 \\
& Pakistan & 3.00 & 24.02 & 43.66 & 17.01 \\
& Sri Lanka & 3.77 & 11.70 & 33.69 & 12.03 \\
& Nepal & - & - & - & - \\
1990 & Bangladesh & 2.59 & 42.37 & 26.89 & 15.21 \\
& India & 0.75 & 10.53 & 3.30 & 3.26 \\
& Pakistan & 1.62 & 10.43 & 14.60 & 9.37 \\
& Sri Lanka & 4.99 & 16.53 & 34.83 & 22.80 \\
& Nepal & - & - & - & - \\
2000 & Bangladesh & 4.15 & 29.67 & 23.34 & 18.02 \\
& India & 2.80 & 21.16 & 12.05 & 12.32 \\
& Pakistan & 1.33 & 9.90 & 8.32 & 8.38 \\
& Sri Lanka & 7.14 & 18.30 & 40.95 & 25.47 \\
& Nepal & 2.03 & 8.72 & 13.38 & 10.50 \\
2010 & Bangladesh & 9.98 & 53.83 & 53.72 & 39.96 \\
& India & 3.07 & 16.64 & 11.79 & 9.79 \\
& Pakistan & 5.09 & 39.49 & 48.50 & 34.01 \\
& Sri Lanka & 7.14 & 18.30 & 40.95 & 25.47 \\
& Nepal & 23.15 & 151.74 & 298.03 & 112.15 \\
\hline
\end{tabular}

Source: World Bank (2011) Remittances World Bank Migration and Remittance Database. GDP, Export earnings, savings, investment data from World Development Indicators.

\section{The literature}

Much of the theoretical work on remittances has been devoted to the primary motive of migrants to remit. ${ }^{4}$ Among the motives put forward are: altruism (Banerjee 1984), insurance (Rosenzweig 1988), investment (Lucas and Stark 1985), inheritance (Hoddinott 1994), risk diversification (Stark and Levhari 1982). There is also a strand of literature which examines macroeconomic financial factors in portfolio choice decision making (Swamy 1981; Katseli and Glytsos 1989; Elbadawi and Rocha 1992; Lianos 1997), which is closely related to the investment motive to remit. Katseli and Glytos (1989) interpret the high level

4 See Lucas and Stark (1985) for hypotheses on the motives to remit. 
of inflation in the home country as a measure of the degree of political and economic uncertainty in that country. Higher inflation may be positively or negatively related to remittance flows depending on the motive to remit. For example, if the motive to remit was self-interest, higher inflation in the home country would reduce remittance flows due to increased uncertainty. Conversely, if altruism were the motive to remit, due to the increased cost of living faced by the migrant workers' family, the volume of remittances would increase. High interest rates on deposits at home similarly could discourage remittance flows as they could be a reflection of high levels of inflation (Elbadawi and Rocha 1992). Alternatively, if remittances were sent with an investment motive, high interest rates at home could increase the volume of remittances (Lianos 1997). The exchange rate similarly can have both a positive or negative effect on remittances. A depreciation of the home currency could lead to an increase in the volume of remittances due to the increased cost of living faced by the family at home or expected future exchange rate rises. It could on the other hand lead to a fall in remittances, if it were a reflection of economic uncertainty. The portfolio diversification or investment motive is closely tied to the concept of risk aversion behaviour of migrants. A risk averse migrant would remit less back home in the event of greater uncertainty.

Remittances received from migrants have become an important source of development finance for developing nations. A number of studies find that migration and remittances have led to an increase in national income, promoted economic growth, and contributed to lowering poverty and income inequality in source countries. For example, Adelman and Taylor (1990) find that for every dollar of remittances coming into Mexico, Mexico's Gross National Income increased by $\$ 2.69-\$ 3.17$. Similarly, Kim (1986) shows that the foreign exchange earnings from South Korean workers migrating to the ME contributed to an increase in Koreas Gross National Product reaching a peak of 3.3\% in 1982. Adams and Page (2003) find that in the Middle East and North Africa (MENA), both remittances and government employment have contributed to low poverty rates and reduced income inequality with a 10 percentage point increase in the share of remittances to GDP reducing the poverty headcount ratio by $5.7 \%$. In a similar study covering a sample of 71 countries, Adams and Page (2005) suggest that migration and remittances contribute to reducing the depth, level, and intensity of poverty, with a $10 \%$ increase in migration leading to a $2.1 \%$ fall in the share of people living below the poverty line of $\$ 1.00$ a day. Similar conclusions are reached by Coombes and Ebeke (2011) who show that remittances reduce consumption instability and act as an insurance policy in the event of negative shocks such as natural disasters, exchange rate, and financial instability in a panel of developing economies. 
Evidence at the microeconomic level also shows that remittance receiving households have been able to reduce poverty and income inequality. Acosta et al. (2008) find that for every percentage point increase in the remittance to GDP ratio, the poverty headcount is reduced by $0.4 \%$ for a group of ten Latin American and Caribbean countries. Similarly Taylor et al. (2005) conclude that remittances have a significant effect on equalizing income inequality in Mexico. Their results suggest that in West-Central Mexico which has the largest number of international migrants, a $10 \%$ increase in international remittances reduces the total income Gini by $0.3 \%$. Remittances have been found to improve the welfare of remittance receiving households in general. Adams (2001) finds that in rural Egypt, households spend $42.5 \%$ on building a new home. In a study of households receiving remittances in Turkey, Koc and Onan (2004) conclude that of all households receiving remittances, about $80 \%$ used is for improving their standard of living. Evidence therefore supports the argument that migration and consequently remittances have significant consequences for a home country. Over the past two decades, remittances have exceeded overseas development aid to developing nations and have proved to be less volatile compared to foreign direct investment.

Much of the literature on migration has revolved around the brain drain argument (Beine, Docquier, and Rapoport 2008; Faini 2007; Niimi, Ozden, and Schiff 2010; Docquier, Lowell, and Marfouk 2009; Docquier, Lohest, and Marfouk 2007, among others). Skill level in these studies is measured by the level of education and the data are primarily drawn from the Docquier and Marfouk (2005) dataset or the OECD database. Docquier and Marfouk (2005) use data on the immigration structure by educational attainment and country of birth from all OECD receiving countries to estimates of emigration stocks and rates by educational attainment. Faini (2007) using the Docquier and Marfouk dataset investigates whether brain drain is associated with a larger flow of remittances into the source country. Faini finds no evidence that skilled workers remit more because skilled migrants tend to spend a longer time period in the host country, weakening their ties with the home country. Similar conclusions are reached by Niimi, Ozden, and Schiff (2010) who investigate whether remittances increase with the education level of migrants'. Also using the Docquier and Marfouk dataset, they find that remittances decrease with the share of migrants with tertiary education. The present study as opposed to these studies places greater emphasis on how unskilled migration affects source country income. The study additionally disaggregates migration and remittances into $\mathrm{ME}$ and other destinations given the large proportion of migrants going to the ME from South Asia. Finally, the skill classification used differs from the literature in that the present study uses the skill classification used by the countries under study (see Section 4 and footnote 7). 


\section{The model and data}

A recursive model that allows the examination of the direct effect of migration on remittances and the indirect effect of migration on the home country's is GDP is employed. ${ }^{5}$ A recursive system, where the endogenous variables are determined sequentially, is employed specifically because it is not possible by definition, to directly estimate the contribution made by the migrant labour force to source country GDP. Remittances are estimated as a mediator between outmigration and the home country's GDP to permit estimation of the contribution made by migrants working overseas. The equation system that is estimated is as follows:

$$
\begin{gathered}
\ln R_{i j t}=\beta_{i} 0+\beta_{1} \ln M_{i j k t}+\beta_{2} \ln M 2_{i t}+\beta_{3} \ln H_{i t}+\beta_{4} \ln O \text { pen }_{i t} \\
+\beta_{5} \ln \pi_{i t}+\beta_{6} r_{i t}+\beta_{7} E_{i t}+\varepsilon_{1} i t \\
\ln Y_{i t}=\alpha_{i} 0+\alpha_{1} \ln R_{i j t}+\alpha_{2} \ln L_{i t}+\alpha_{3} \ln K_{i t}+\alpha_{4} \ln H_{i t}+\alpha_{5} \ln M 2_{i t}+\varepsilon_{2} i t
\end{gathered}
$$

Eq. [1], models remittance flows $(R)$, from country $j$ (ME and other destinations), ${ }^{6}$ into country $i$ in period $t$, as a function of migration $(M)$ by skill level $k$ (migrants are divided into five categories by skill level: where $M_{P}=$ the number of professionally qualified migrants; $M_{O W}=$ other white collar migrants; $M_{S}=$ the number of skilled migrants; $M_{S S}=$ the number of semi-skilled migrants and $M_{u}=$ the number of unskilled migrants ${ }^{7}$ ) to country $j$ from country $i$ in period $t$, and other control variables. A better developed financial sector will lead to a higher volume of remittances being transmitted (Giuliano and Ruiz-

5 Rozelle, Taylor, and deBrauw (1999) have used a recursive system to estimate the effects of migration and remittances in China on agricultural production.

$6 M$, is further divided into two components: migration to the ME and the Gulf $\left(M_{M E E}\right)$ and migration to other countries ( $M_{\text {other }}$ ) and remittances, $R$, is also divided into: remittances from the ME $\left(R_{M E}\right)$, and remittances from other destinations ( $\left.R_{\text {other }}\right)$.

7 The definition of these migrant categories is as follows: (1) Professionals are those who are tertiary qualified for example, doctors, lawyers, and engineers. (2) Other white collar workers are those with secondary qualifications, for example, administrative and managerial staff (the highly skilled group in Pakistan, mid-level group in Sri Lanka and white collar workers in India fall into this group. Bangladesh does not have this category). (3) Those who fall into the skilled labour category are those who have received specialised training in particular trades, for example, plumbers, carpenters. (4) Someone who has knowledge of a particular job, but is not qualified or received specialised training, for example, tailors, masons fall into the semiskilled category. (5) Workers with no qualifications or training, for example, housemaids, labourers fall into the unskilled group. 
Arranz 2009); therefore, $M 2$ is used to capture the level of financial development of the home country. $H$ is the secondary enrolment ratio designed to capture the level of education in the country of origin. The empirical estimation also includes the degree of trade openness (Open) measured by the sum of exports and imports (see Chami, Hakura, and Montiel 2009), as the more open an economy, the higher the inflow of remittances. The rate of inflation $(\pi)$, interest rate $(r)$, and exchange rate movements $(E)$ are also assumed to determine the volume of remittances sent to the home country as a strand of literature examines macroeconomic financial factors in portfolio choice decision making or the investment motive of migrants (Swamy 1981; Katseli and Glytsos 1989). The portfolio choice decision-making variables, inflation, the rate of interest, and exchange rate in equation are used in an attempt to capture the motive of migrants to remit. These variables can have either a positive or negative effect on the volume of remittances as mentioned in Section 3 above.

Eq. [2], models Gross Domestic Product, in the origin country $i$ in period $t$ as a function of remittance flows $(R)$, from country $j$ to $i$ in time period $t$. The other control variables in eq. [2] comprise a set of variables that are commonly used in the growth literature. These variables include the domestic labour force, $L$, to capture the effects of the domestic labour force which is a fundamental determinant of economic growth, the stock of physical capital, $K$, as well developed infrastructural facilities can lead to an increase in the transfer of remittances, the secondary enrolment ratio, $H$, to control for the stock of human capital and $M 2$ to capture financial sector development. $\varepsilon_{1 i t}$ and $\varepsilon_{2 i t}$ are random disturbance terms that capture the aggregate effect of all other factors. The level of GDP rather than GDP per capita is used given that the model incorporates both the local and migrant labour force. Therefore the study investigates the effect of migration on the level of remittances and consequently the level of GDP. ${ }^{8}$

The data are annual and cover the 1976 to 2010 period for Bangladesh, India, Pakistan, and Sri Lanka. Only total migration and total remittance data are available for Nepal, and hence Nepal is included in the aggregate estimations. Data are drawn from several sources. Data sources are provided in Table 8 of the Appendix. Descriptive statistics for the variables used in the study are provided in Table 9 of the Appendix.

8 The level of GDP is also used by Lueth and Ruiz-Arranz (2008) and Niimi, Ozden, and Schiff (2010). Lueth and Ruiz-Arranz (2008) note that policymakers in sending countries are interested policies that promote remittances and how they affect GDP in the host country. 


\section{Empirical results}

Ordinary Least Squares (OLS) can be used to estimate a recursive system if the endogenous variables are determined sequentially and the error terms of the two equations are not correlated. Although eqs [1] and [2] comprise a recursive system, the remittances and GDP could be endogenously determined. A country's level of GDP could also be a determinant of the amount of remittances it receives. Moreover, if there exists a common set of omitted variables from the two equations, this could lead to correlation between the error terms. Therefore, the 3SLS estimator is used to correct for the possibility of endogeneity and correlation between the error terms (see Rozelle, Taylor, and deBrauw 1999). The estimation is also carried out using the seemingly unrelated regression method (SUR) to check the robustness of the results to the estimation procedure. The SUR technique is a systems estimator which takes into account correlations of the residuals across equations and therefore interdependence between the error terms. An advantage of using SUR is that it yields more efficient estimates, as opposed to estimating the equations separately by using OLS (Devadoss and Foltz 1996).

The 3SLS results for the effects of migration and remittances on real GDP are presented in Table 3.

The direct impact of migration on remittances is positive and significant. A $1 \%$ increase in the number of migrants for example leads to an increase in remittances of $0.20 \%$ in column (1). Similarly total remittances have a positive and significant effect on GDP. In column (2), a 1\% increase in remittances leads to a $0.53 \%$ increase in real GDP. A question that this study attempts to answer is, what the indirect impact of migration is on GDP. ${ }^{9}$ The estimated coefficients in columns (1) and (2) suggest that the indirect effect of migration on GDP through the mediating variable remittances accounts for $35 \%$ while the direct effect of migration on remittances is $65 \%$ (see Table 7 for calculation of indirect effects). Openness and the level of financial sector development have a positive and significant effect on remittances. This is reasonable considering that the more open and better developed a country's financial system, the easier it would be to remit money. In column (3), additional control variables are added to the remittance equation in an attempt to capture the motives to remit. The coefficient on the rate of inflation is positive and significant suggesting that an increase in home country inflation leads to a higher volume of remittances. Similarly, the coefficient on the exchange rate is negative and significant

9 The total effect is the sum of the direct influence of the exogenous variable, $M$, on the endogenous variable $R$, plus the indirect effect of $M$ on GDP through the mediating variable $R$. The indirect effect is calculated by multiplying the direct effects corresponding to the indirect effects. 
Table 3: Effects of migration and remittances on GDP - three stage least squares

\begin{tabular}{|c|c|c|c|c|c|c|}
\hline \multirow{3}{*}{$\begin{array}{l}\text { Independent } \\
\text { variables }\end{array}$} & (1) & (2) & (3) & (4) & (5) & (6) \\
\hline & \multicolumn{6}{|c|}{ Dependent variables } \\
\hline & $\boldsymbol{R}_{\text {total }}$ & $\boldsymbol{Y}$ & $\boldsymbol{R}_{\text {total }}$ & $\boldsymbol{r}$ & $\boldsymbol{R}_{\text {total }}$ & $\boldsymbol{r}$ \\
\hline$R_{\text {total }}$ & - & $\begin{array}{c}0.531 \\
(0.040)^{\star \star \star \star}\end{array}$ & - & $\begin{array}{c}0.423 \\
(0.052)^{* * *}\end{array}$ & - & $\begin{array}{c}0.198 \\
(0.054)^{\star \star \star *}\end{array}$ \\
\hline$M_{\text {total }}$ & $\begin{array}{c}0.201 \\
(0.063)^{\star \star \star}\end{array}$ & - & $\begin{array}{c}0.181 \\
(0.023)^{\star \star}\end{array}$ & - & - & - \\
\hline$M_{P}$ & - & - & - & - & $\begin{array}{r}0.187 \\
(0.169)\end{array}$ & - \\
\hline Mow & - & - & - & - & $\begin{array}{r}0.014 \\
(0.064)\end{array}$ & - \\
\hline$M_{S}$ & - & - & - & - & $\begin{array}{c}0.374 \\
(0.113)^{\star \star *}\end{array}$ & - \\
\hline Mss & - & - & - & - & $\begin{array}{r}0.147 \\
(0.121)\end{array}$ & - \\
\hline$M_{U}$ & - & - & - & - & $\begin{array}{c}0.521 \\
(0.108)^{\star \star \star}\end{array}$ & - \\
\hline$L$ & - & $\begin{array}{c}0.506 \\
(0.023)^{* * *}\end{array}$ & - & $\begin{array}{c}0.025 \\
(0.015)^{\star}\end{array}$ & - & $\begin{array}{c}0.314 \\
(0.112)^{\star \star \star}\end{array}$ \\
\hline$K$ & - & $\begin{array}{c}0.176 \\
(0.025)^{\star * * *}\end{array}$ & - & $\begin{array}{c}0.153 \\
(0.010)^{* * *}\end{array}$ & - & $\begin{array}{c}0.214 \\
(0.101)^{\star \star}\end{array}$ \\
\hline$H$ & $\begin{array}{r}0.236 \\
(0.177)\end{array}$ & $\begin{array}{c}0.185 \\
(0.035)^{\star \star \star \star}\end{array}$ & $\begin{array}{c}0.194 \\
(0.029)^{\star * *}\end{array}$ & $\begin{array}{c}0.307 \\
(0.164)^{\star \star}\end{array}$ & - & $\begin{array}{c}0.234 \\
(0.011)^{\star \star}\end{array}$ \\
\hline M2 & $\begin{array}{c}0.599 \\
(0.057)^{k \star k *}\end{array}$ & $\begin{array}{c}0.311 \\
(0.058)^{\star \star \star}\end{array}$ & $\begin{array}{c}0.093 \\
(0.007)^{\star \star \star *}\end{array}$ & $\begin{array}{c}0.343 \\
(0.024)^{\star \star \star k}\end{array}$ & $\begin{array}{c}0.430 \\
(0.088)^{\star * \star}\end{array}$ & $\begin{array}{c}0.311 \\
(0.109)^{\star \star \star}\end{array}$ \\
\hline Open & $\begin{array}{c}0.368 \\
(0.154)^{\star \star \star}\end{array}$ & - & $\begin{array}{c}0.126 \\
(0.031)^{\star \star \star \star}\end{array}$ & - & $\begin{array}{c}0.249 \\
(0.010)^{k * k}\end{array}$ & - \\
\hline$\pi$ & - & - & $\begin{array}{c}0.030 \\
(0.011)^{\star \star \star}\end{array}$ & - & - & - \\
\hline$R$ & - & - & $\begin{array}{l}-0.027 \\
(0.020)\end{array}$ & - & - & - \\
\hline $\boldsymbol{E}$ & - & - & $\begin{array}{l}-0.032 \\
(0.005)^{\star \star \star}\end{array}$ & - & - & - \\
\hline$R^{2}$ & 0.81 & 0.90 & 0.89 & 0.89 & 0.75 & 0.90 \\
\hline Observations & 122 & 122 & 115 & 115 & 76 & 76 \\
\hline
\end{tabular}

Notes: Standard errors reported in parenthesis. ${ }^{\star \star \star}$, **, * significant at the $1 \%, 5 \%$ and $10 \%$ levels respectively. 
implying that exchange rate depreciation leads to a higher volume of remittances, suggesting perhaps that an increase in cost of living leads to higher remittance flows. There is some support therefore for the altruistic motive. The results for migration disaggregated by skill level are reported in column (5). The results suggest that the skilled and unskilled groups have a positive significant impact on remittances. The coefficients on the professional, other white collar workers, and semi-skilled categories are not statistically significant. The largest significant effect is from the unskilled group suggesting that a $1 \%$ increase in unskilled migration will lead to a $0.52 \%$ increase in remittances. The unskilled category has an indirect effect of $17 \%$ on home country GDP (see Table 7). The skill disaggregated models were also estimated with the portfolio choice variables (these results are not reported as the number of observations drops significantly). However, as before the coefficient on inflation was positive and significant and that on the exchange rate negative and significant providing some evidence in favour of the altruistic motive. Remittances have a positive and statistically significant effect on real GDP in column (6). The domestic labour force, stock of capital, enrolment ratio, and financial sector development have a statistically significant positive effect on GDP.

The estimation in Table 3 is replicated by using the SUR estimation method. The results are reported on Table 4.

The results corroborate the findings above. A $1 \%$ increase in total migration leads to a $0.42 \%$ increase in total remittance income in column (1). The calculated indirect effect of migration on GDP from the estimated coefficients in columns (1) and (2) is $26 \%$ (see Table 7). Total remittances have a positive and significant effect on real GDP in columns (2), (4) and (6), suggesting the importance of remittances for South Asia. The domestic labour force, stock of capital, enrolment ratio, and financial sector development continue to have a statistically significant positive effect on GDP. Column (3) incorporates the portfolio choice decision-making variables, home country inflation, the deposit rate, and exchange rate. The coefficient on inflation is positive and statistically significant and the coefficients on the interest rate and exchange rate are negative and statistically significant, providing some evidence in favour of altruistic motive. In the results disaggregated by skill level in column (5), the coefficients on the number of skilled, semi-skilled, and unskilled migrants are statistically significant. Once again, the unskilled group has the greatest significant effect on remittances with a $1 \%$ increase in unskilled migration leading to a $0.51 \%$ increase in remittances. The number of unskilled migrants has the largest indirect effect on GDP contributing to 19\% (see Table 7). Migration continues to have a positive significant indirect effect on GDP controlling for other variables. 
Table 4: Effects of migration and remittances on GDP - SUR

\begin{tabular}{|c|c|c|c|c|c|c|}
\hline \multirow{3}{*}{$\begin{array}{l}\text { Independent } \\
\text { variables }\end{array}$} & (1) & (2) & (3) & (4) & (5) & (6) \\
\hline & \multicolumn{6}{|c|}{ Dependent variables } \\
\hline & $\boldsymbol{R}_{\text {total }}$ & $r$ & $\boldsymbol{R}_{\text {total }}$ & $\boldsymbol{Y}$ & $\boldsymbol{R}_{\text {total }}$ & $\boldsymbol{r}$ \\
\hline$R_{\text {total }}$ & - & $\begin{array}{c}0.355 \\
(0.100)^{\star \star *}\end{array}$ & - & $\begin{array}{c}0.449 \\
(0.193)^{\star * \star}\end{array}$ & - & $\begin{array}{c}0.230 \\
(0.068)^{\star \star \star \star}\end{array}$ \\
\hline$M_{\text {total }}$ & $\begin{array}{c}0.421 \\
(0.143)^{\star \star \star}\end{array}$ & - & $\begin{array}{c}0.308 \\
(0.102)^{\star \star}\end{array}$ & - & - & - \\
\hline$M_{P}$ & - & - & - & - & $\begin{array}{r}0.160 \\
(0.141)\end{array}$ & - \\
\hline Mow & - & - & - & - & $\begin{array}{r}0.021 \\
(0.024)\end{array}$ & - \\
\hline$M_{s}$ & - & - & - & - & $\begin{array}{c}0.312 \\
(0.110)^{\star \star *}\end{array}$ & - \\
\hline$M_{s S}$ & - & - & - & - & $\begin{array}{c}0.140 \\
(0.090)^{\star}\end{array}$ & - \\
\hline$M_{u}$ & - & - & - & - & $\begin{array}{c}0.501 \\
(0.112)^{\star * \star}\end{array}$ & - \\
\hline$L$ & - & $\begin{array}{c}0.312 \\
(0.112)^{\star \star \star \star}\end{array}$ & - & $\begin{array}{c}0.289 \\
(0.010)^{\star * \star}\end{array}$ & - & $\begin{array}{l}0.280 \\
(0.117)^{k \star \star}\end{array}$ \\
\hline$\kappa$ & - & $\begin{array}{c}0.106 \\
(0.009)^{\star \star \star}\end{array}$ & - & $\begin{array}{c}0.113 \\
(0.022)^{\star \star \star \star}\end{array}$ & - & $\begin{array}{c}0.230 \\
(0.120)^{\star \star}\end{array}$ \\
\hline$H$ & $\begin{array}{r}0.106 \\
(0.109)\end{array}$ & $\begin{array}{c}0.112 \\
(0.024)^{\star \star \star}\end{array}$ & $\begin{array}{r}0.104 \\
(0.120)\end{array}$ & $\begin{array}{c}0.316 \\
(0.153)^{\star *}\end{array}$ & - & $\begin{array}{c}0.180 \\
(0.097)^{\star \star \star}\end{array}$ \\
\hline$M 2$ & $\begin{array}{c}0.257 \\
(0.107)^{\star * *}\end{array}$ & $\begin{array}{c}0.236 \\
(0.048)^{\star \star \star}\end{array}$ & $\begin{array}{c}0.213 \\
(0.101)^{\star \star}\end{array}$ & $\begin{array}{c}0.240 \\
(0.116)^{\star \star}\end{array}$ & $\begin{array}{c}0.320 \\
(0.061)^{\star \star \star}\end{array}$ & $\begin{array}{c}0.321 \\
(0.112)^{\star \star \star \star}\end{array}$ \\
\hline Open & $\begin{array}{c}0.218 \\
(0.104)^{\star *}\end{array}$ & - & $\begin{array}{c}0.240 \\
(0.042)^{\star \star \star}\end{array}$ & - & $\begin{array}{c}0.212 \\
(0.097)^{\star *}\end{array}$ & - \\
\hline$\pi$ & - & - & $\begin{array}{c}0.020 \\
(0.010)^{\star \star}\end{array}$ & - & - & - \\
\hline$r$ & - & - & $\begin{array}{l}-0.019 \\
(0.010)^{\star}\end{array}$ & - & - & - \\
\hline$E$ & - & - & $\begin{array}{l}-0.029 \\
(0.009)^{\star \star \star}\end{array}$ & - & - & - \\
\hline Observations & 122 & 122 & 115 & 115 & 76 & 76 \\
\hline
\end{tabular}

Notes: Standard errors reported in parenthesis. ${ }^{\star \star *},{ }^{\star \star},{ }^{*}$ significant at the $1 \%, 5 \%$ and $10 \%$ levels respectively. 
Given the large-scale migration to the ME from South Asia, next migration and remittances are divided into migration to and remittances from: (1) the ME and (2) other destinations. Three equations are estimated here for: remittances from the ME $\left(R_{M E}\right)$, remittances from other destinations $\left(R_{\text {other }}\right)$ and GDP $(Y)$. Results using 3SLS for effects by country of destination are reported on Table 5. The results indicate that migration to the ME and other destinations have a positive significant effect at the $1 \%$ and $10 \%$ levels of significance respectively on remittances from these regions. The magnitude of the coefficient on remittances from the ME in column (1) is larger than that on remittances from other destinations in column (2). ME migration has a larger positive indirect effect on output through remittances from the ME. This is not surprising given the large number of workers migrating in search of employment to the ME from these nations. The estimated coefficients in columns (1) and (3) indicate that the indirect effect of ME migration on GDP accounts for $22 \%$ of the total effect and the estimated coefficients in columns (2) and (3) that the indirect effect of migration to other destinations on GDP 15\% (see Table 7 for calculation). The coefficients on the motives to remit in the ME remittance equation in column (1) provide some evidence in favour of the altruistic motive. The coefficient on the rate of interest in column (2) - remittances from other countries - is positive and significant suggesting that higher interest rates in the home country lead to higher remittances providing some evidence in favour of the investment motive. An examination of the skill-level disaggregated equations in column (4) indicates that the professional, semi-skilled, and unskilled groups have a positive significant effect on remittances from the ME, while the skilled and unskilled groups have a significant effect on remittances from other destinations. Column (4) indicates that a $1 \%$ increase in the migration of professionals to the ME leads to a $0.30 \%$ increase in remittances from the $\mathrm{ME}$, while unskilled migration to the ME contributes $0.52 \%$ to remittances from the ME. In column (5), the migration of professionals to other destinations is not statistically significant, while a $1 \%$ increase in unskilled migration to other destinations leads to a $0.17 \%$ increase in remittances from other regions. Using estimates in columns (4) and (6) to calculate indirect effects (see Table 7), the unskilled group that migrates to the ME have the largest indirect effect on GDP contributing to $33 \%$, and based on the estimates in columns (5) and (6), the unskilled group to other destinations contributes to $14 \%$. This is possibly because unskilled migration tends to be largely temporary compared to other categories. Of the statistically significant coefficients on the skill categories, the greater magnitude of those on the ME coefficients is also possibly due to the fact that migration to the ME is largely temporary and therefore a larger proportion of those earnings are remitted back. The results on Table 5 also indicate that remittances from the ME have a strong 
Table 5: Effects by country of destination - three stage least squares

\begin{tabular}{|c|c|c|c|c|c|c|}
\hline \multirow{3}{*}{$\begin{array}{l}\text { Independent } \\
\text { variables }\end{array}$} & (1) & (2) & (3) & (4) & (5) & (6) \\
\hline & \multicolumn{6}{|c|}{ Dependent variables } \\
\hline & $R_{M E}$ & $\boldsymbol{R}_{\text {other }}$ & $\boldsymbol{r}$ & $R_{M E}$ & $\boldsymbol{R}_{\text {other }}$ & $r$ \\
\hline$R_{M E}$ & - & - & $\begin{array}{c}0.289 \\
(0.039)^{\star \star \star}\end{array}$ & - & - & $\begin{array}{c}0.498 \\
(0.127)^{\star \star \star \star}\end{array}$ \\
\hline$R_{\text {other }}$ & - & - & $\begin{array}{c}0.172 \\
(0.069)^{\star \star \star \star}\end{array}$ & - & - & $\begin{array}{c}0.156 \\
(0.065)^{\star}\end{array}$ \\
\hline$M_{M E}$ & $\begin{array}{c}0.333 \\
(0.050)^{\star \star \star}\end{array}$ & & - & - & - & - \\
\hline$M_{\text {other }}$ & - & $\begin{array}{c}0.071 \\
(0.039)^{\star}\end{array}$ & - & - & - & - \\
\hline$M_{P}$ & & & - & $\begin{array}{c}0.297 \\
(0.141)^{\star \star}\end{array}$ & $\begin{array}{r}0.106 \\
(0.143)\end{array}$ & - \\
\hline Mow & - & - & - & $\begin{array}{r}0.071 \\
(0.173)\end{array}$ & $\begin{array}{r}0.255 \\
(0.256)\end{array}$ & - \\
\hline$M_{S}$ & - & - & - & $\begin{array}{r}0.032 \\
(0.054)\end{array}$ & $\begin{array}{c}0.220 \\
(0.129)^{\star}\end{array}$ & - \\
\hline$M_{s s}$ & - & - & - & $\begin{array}{c}0.400 \\
(0.208)^{\star \star}\end{array}$ & $\begin{array}{r}0.079 \\
(0.300)\end{array}$ & - \\
\hline$M_{U}$ & - & - & - & $\begin{array}{c}0.522 \\
(0.127)^{\star \star \star}\end{array}$ & $\begin{array}{c}0.170 \\
(0.023)^{\star * \star}\end{array}$ & - \\
\hline$L$ & - & - & $\begin{array}{c}0.235 \\
(0.082)^{\star \star \star}\end{array}$ & - & - & $\begin{array}{c}0.127 \\
(0.041)^{\star \star \star *}\end{array}$ \\
\hline$\kappa$ & - & - & $\begin{array}{c}0.229 \\
(0.129)^{*}\end{array}$ & - & - & $\begin{array}{c}0.210 \\
(0.102)^{\star \star}\end{array}$ \\
\hline$H$ & $\begin{array}{c}0.426 \\
(0.168)^{\star \star \star}\end{array}$ & $\begin{array}{c}0.075 \\
(0.039)^{\star \star \star}\end{array}$ & $\begin{array}{c}0.362 \\
(0.121)^{\star * *}\end{array}$ & - & - & $\begin{array}{c}0.268 \\
(0.114)^{\star \star \star}\end{array}$ \\
\hline M2 & $\begin{array}{c}0.073 \\
(0.005)^{\star \star \star}\end{array}$ & $\begin{array}{c}0.097 \\
(0.009)^{* * *}\end{array}$ & $\begin{array}{c}0.486 \\
(0.172)^{\star \star \star *}\end{array}$ & $\begin{array}{c}0.056 \\
(0.024)^{\star \star *}\end{array}$ & $\begin{array}{c}0.036 \\
(0.012)^{\star \star}\end{array}$ & $\begin{array}{c}0.325 \\
(0.125)^{\star \star \star \star}\end{array}$ \\
\hline Open & $\begin{array}{c}0.506 \\
(0.167)^{\star \star \star}\end{array}$ & $\begin{array}{c}0.103 \\
(0.030)^{\star \star \star}\end{array}$ & - & $\begin{array}{c}0.042 \\
(0.015)^{* * *}\end{array}$ & $\begin{array}{c}0.027 \\
(0.010)^{\star \star \star}\end{array}$ & - \\
\hline$\pi$ & $\begin{array}{c}0.005 \\
(0.002)^{\star \star \star}\end{array}$ & $\begin{array}{r}0.005 \\
(0.009)\end{array}$ & - & - & - & - \\
\hline$r$ & $\begin{array}{r}0.013 \\
(0.010)\end{array}$ & $\begin{array}{c}0.050 \\
(0.019)^{\star \star \star}\end{array}$ & - & - & - & - \\
\hline$E$ & $\begin{array}{l}-0.006 \\
(0.003)^{*}\end{array}$ & $\begin{array}{l}-0.009 \\
(0.005)^{\star}\end{array}$ & - & - & - & - \\
\hline$R^{2}$ & 0.98 & 0.90 & 0.98 & 0.66 & 0.48 & 0.60 \\
\hline Observations & 66 & 66 & 66. & 55 & 55 & 55 \\
\hline
\end{tabular}

Notes: Standard errors reported in parenthesis. ${ }^{* \star \star},{ }^{\star \star},{ }^{*}$ significant at the $1 \%, 5 \%$ and $10 \%$ levels respectively. 
significant impact on GDP in column (6) and remittances from other regions are significant at the $10 \%$ level. As observed by Glytos (1997) "remittances from permanent migrants are a byproduct of migration, and remittances from temporary migrants a main product of migration."

The estimation carried out in Table 5 is replicated using panel SUR estimation in Table 6. Turning to the main variables of interest, ME remittances and migration continue to have a positive significant effect on GDP and remittances. A $1 \%$ increase in migration to the ME is associated with a $0.22 \%$ increase in remittances from the ME in column (1) and a $1 \%$ increase in migration to other destinations is associated with an increase in remittances from other destinations by $0.09 \%$ in column (2). The skill disaggregated results reported in columns (4) and (5) indicate that the unskilled group has the largest significant effect on remittances from the ME and remittances from other destinations. The coefficients on the professional group are also statistically significant in both columns (4) and (5) and the semi-skilled group also contributes significantly to remittances from the ME. However, the unskilled group continues to have a significant and robust effect on remittances signifying the importance of unskilled workers to remittance income and therefore GDP in South Asia. Remittances from the ME and other destinations have a significant positive effect on real GDP in columns (3) and (6); however, remittances from the ME have a greater impact on real GDP.

\subsection{Calculation of indirect effects}

A question that this study attempts to answer is what the indirect impact of migration is on GDP (Y): see footnote 9. As mentioned in Section 3, it is not possible by definition to directly estimate the contribution made by the migrant labour force to the home country's income. Therefore, the indirect effect of migration, $M$, on $Y$ is calculated by multiplying the direct effect of $M$ on $R$ by the effect of $R$ on $Y$. Columns (1) and (2) of Table 7 indicate the Tables and columns from which the estimates are taken for calculating direct and indirect effects. The direct effect reported in column (3) is the net effect of migration on remittances that is not transmitted through the mediating variable, remittances. The indirect effect in column (4) is the effect of migration on real $Y$ transmitted though the mediating variable remittances (that is: $M \rightarrow R \rightarrow Y$ ). The total effect in column (5) is the sum of the direct effect + indirect effects. The proportion that the indirect effect accounts for, of the total effect is calculated as the (indirect effect/total effect) ${ }^{\star} 100$. 
Table 6: Effects by country of destination - SUR

\begin{tabular}{|c|c|c|c|c|c|c|}
\hline \multirow{3}{*}{$\begin{array}{l}\text { Independent } \\
\text { variables }\end{array}$} & (1) & (2) & (3) & (4) & (5) & (6) \\
\hline & \multicolumn{6}{|c|}{ Dependent variables } \\
\hline & $R_{M E}$ & $\boldsymbol{R}_{\text {other }}$ & $\boldsymbol{r}$ & $R_{M E}$ & $\boldsymbol{R}_{\text {other }}$ & $\mathbf{r}$ \\
\hline$R_{M E}$ & - & - & $\begin{array}{c}0.326 \\
(0.045)^{\star \star \star}\end{array}$ & - & - & $\begin{array}{c}0.314 \\
(0.076)^{* k \star}\end{array}$ \\
\hline$R_{\text {other }}$ & - & - & $\begin{array}{c}0.131 \\
(0.066)^{* *}\end{array}$ & - & - & $\begin{array}{c}0.132 \\
(0.064)^{\star \star}\end{array}$ \\
\hline$M_{M E}$ & $\begin{array}{c}0.215 \\
(0.078)^{\star \star \star *}\end{array}$ & & - & - & - & - \\
\hline$M_{\text {other }}$ & - & $\begin{array}{c}0.092 \\
(0.041)^{\star *}\end{array}$ & - & - & - & - \\
\hline$M_{P}$ & & & - & $\begin{array}{c}0.290 \\
(0.138)^{\star \star \star}\end{array}$ & $\begin{array}{c}0.025 \\
(0.018)^{*}\end{array}$ & - \\
\hline Mow & - & - & - & $\begin{array}{r}0.065 \\
(0.143)\end{array}$ & $\begin{array}{r}0.152 \\
(0.112)\end{array}$ & - \\
\hline$M_{s}$ & - & - & - & $\begin{array}{r}0.056 \\
(0.042)\end{array}$ & $\begin{array}{r}0.120 \\
(0.124)\end{array}$ & - \\
\hline$M_{s s}$ & - & - & - & $\begin{array}{c}0.215 \\
(0.105)^{\star \star}\end{array}$ & $\begin{array}{r}0.034 \\
(0.041)\end{array}$ & - \\
\hline$M_{U}$ & - & - & - & $\begin{array}{c}0.459 \\
(0.194)^{\star * * *}\end{array}$ & $\begin{array}{c}0.156 \\
(0.023)^{\star * \star \star}\end{array}$ & - \\
\hline$L$ & - & - & $\begin{array}{c}0.197 \\
(0.061)^{\star \star * *}\end{array}$ & - & $\rightarrow$ & $\begin{array}{c}0.110 \\
(0.021)^{\star \star \star}\end{array}$ \\
\hline$\kappa$ & - & - & $\begin{array}{c}0.250 \\
(0.116)^{\star \star}\end{array}$ & - & - & $\begin{array}{c}0.235 \\
(0.106)^{\star \star}\end{array}$ \\
\hline$H$ & $\begin{array}{r}0.112 \\
(0.145)\end{array}$ & $\begin{array}{c}0.176 \\
(0.023)^{\star \star \star \star}\end{array}$ & $\begin{array}{c}0.245 \\
(0.118)^{\star \star}\end{array}$ & - & - & $\begin{array}{c}0.271 \\
(0.101)^{\star \star \star}\end{array}$ \\
\hline$M 2$ & $\begin{array}{c}0.187 \\
(0.017)^{\star \star \star}\end{array}$ & $\begin{array}{c}0.075 \\
(0.012)^{\star \star \star}\end{array}$ & $\begin{array}{c}0.326 \\
(0.117)^{\star \star \star}\end{array}$ & $\begin{array}{c}0.045 \\
(0.019)^{\star \star \star}\end{array}$ & $\begin{array}{c}0.058 \\
(0.020)^{\star \star \star}\end{array}$ & $\begin{array}{c}0.228 \\
(0.110)^{\star *}\end{array}$ \\
\hline Open & $\begin{array}{c}0.415 \\
(0.136)^{\star \star \star \star}\end{array}$ & $\begin{array}{c}0.118 \\
(0.056)^{\star \star}\end{array}$ & - & $\begin{array}{c}0.025 \\
(0.011)^{* \star \star}\end{array}$ & $\begin{array}{c}0.134 \\
(0.014)^{* * *}\end{array}$ & - \\
\hline$\pi$ & $\begin{array}{c}0.008 \\
(0.003)^{\star \star \star}\end{array}$ & $\begin{array}{r}0.006 \\
(0.006)\end{array}$ & - & - & - & - \\
\hline$r$ & $\begin{array}{l}-0.010 \\
(0.006)^{\star}\end{array}$ & $\begin{array}{c}0.020 \\
(0.010)^{\star \star *}\end{array}$ & - & - & - & - \\
\hline$E$ & $\begin{array}{l}-0.006 \\
(0.003)^{\star}\end{array}$ & $\begin{array}{l}-0.008 \\
(0.004)^{\star \star}\end{array}$ & - & - & - & - \\
\hline Observations & 66 & 66 & 66 & 55 & 55 & 55 \\
\hline
\end{tabular}

Notes: Standard errors reported in parenthesis. ***, **, * significant at the $1 \%, 5 \%$ and $10 \%$ levels respectively. 
Table 7: Indirect effects of remittances on GDP

\begin{tabular}{|c|c|c|c|c|c|}
\hline (1) & (2) & (3) & (4) & (5) & (6) \\
\hline Table & Coefficient & $\begin{array}{r}\text { Direct } \\
\text { effect }(D I)\end{array}$ & $\begin{array}{r}\text { Indirect } \\
\text { effect (IE) }\end{array}$ & $\begin{array}{r}\text { Total } \\
\text { effect (TE) }\end{array}$ & $\begin{array}{l}\text { Indirect } \\
\text { effect \% }\end{array}$ \\
\hline . & & $\hat{\hat{\beta}_{1}}$ & $\hat{\boldsymbol{\beta}}_{1}^{*} \hat{\boldsymbol{a}}_{1}$ & (DI) + (IE) & (IE/TE)*100 \\
\hline \multicolumn{6}{|c|}{ Total migration and remittances ${ }^{a}$} \\
\hline Table 3 & Columns (1) \& (2) & 0.201 & 0.107 & 0.308 & 35 \\
\hline Table 3 & Columns (3) \& (4) & 0.181 & 0.077 & 0.256 & 29 \\
\hline Table 4 & Columns (1) \& (2) & 0.421 & 0.149 & 0.570 & 26 \\
\hline Table 4 & Columns (3) \& (4) & 0.308 & 0.138 & 0.446 & 31 \\
\hline \multicolumn{6}{|c|}{ ME and other migration and remittances ${ }^{b}$} \\
\hline Table 5 & Columns (1) \& (3) & 0.333 & 0.096 & 0.429 & 22 \\
\hline Table 5 & Columns (2) \& (3) & 0.071 & 0.012 & 0.083 & 15 \\
\hline Table 6 & Columns (1) \& (3) & 0.215 & 0.070 & 0.285 & 25 \\
\hline Table 6 & Columns (2) \& (3) & 0.092 & 0.012 & 0.104 & 12 \\
\hline \multicolumn{6}{|c|}{ Unskilled migration and remittances ${ }^{c}$} \\
\hline Table 3 & Columns (5) \& (6) & 0.521 & 0.103 & 0.624 & 17 \\
\hline Table 4 & Columns (5) \& (6) & 0.501 & 0.115 & 0.616 & 19 \\
\hline Table 5 & Columns (4) \& (6) & 0.522 & 0.260 & 0.782 & 33 \\
\hline Table 5 & Columns (5) \& (6) & 0.17 & 0.027 & 0.197 & 14 \\
\hline Table 6 & Columns (4) \& (6) & 0.459 & 0.144 & 0.603 & 24 \\
\hline Table 6 & Columns (5) \& (6) & 0.156 & 0.021 & 0.177 & 12 \\
\hline
\end{tabular}

Notes: a Based upon estimates for total migration and remittances in Tables 3 and 4. ${ }^{\text {b Based }}$ upon estimates for ME and other destinations in Tables 5 and 6. 'Based upon estimates for the unskilled group in Tables 3-6.

The results reported in the first row for example, based upon the estimated coefficients with 3SLS in column (1) and (2) of Table 3 for migration and remittances, suggest that the indirect effect of migration on GDP through the mediating variable remittances accounts for $35 \%$, and the direct effect of migration on remittances is $65 \%$. The results presented in the first and second rows below ME and Other Migration and Remittances based on the coefficients in Table 5 suggest that the indirect effect of ME migration on GDP via remittances accounts for $22 \%$ of the total effect highlighting the important of ME migration for the level of income in the countries under study as opposed to $15 \%$ of the total effect for remittances from other destinations. The indirect component for unskilled workers based on the coefficients in Table 5 shows that unskilled workers account for 33\% of the total effect of ME migration on GDP mediated through ME remittances. The results suggest that even after controlling for other 
factors, ME migration continues to have both, an important direct effect on remittances and indirect effect on GDP.

\section{Policy implications and conclusions}

The results provide strong evidence in favour of the hypothesis that migration and remittances have an important significant effect on the GDP of South Asia. The results are consistent with those of Adelman and Taylor (1990) and Kim (1986) among others who find migration and therefore remittances contribute positively to source country income. The present study also finds that the unskilled category has the largest robust indirect effect on GDP through total remittances. The effects of migration on GDP by country of destination, divided into Middle East and other destinations, suggest that migration to the ME has an important statistically significant effect on GDP via remittances. Similar conclusions are reached by Kim (1986) for South Korea. Additionally, as observed by Glytos (1997), temporary migrants exhibit a different remitting pattern from permanent migrants. They usually have a target of accumulating an amount of savings by postponing current consumption in the host country. The results of the present study indicate that the unskilled category has the largest robust indirect effect on GDP also through ME remittances. This is possibly due to the fact that this is the largest migratory category in number, unskilled migration to the $\mathrm{ME}$ is largely temporary and the frequency with which the unskilled group remits is higher. The results are consistent with those of Niimi, Ozden, and Schiff (2010) who find that remittances decline with the share of migrants who are tertiary qualified, and Faini (2007) who finds no evidence of skilled migrants remitting more. The results appear to suggest that the motive of migrants' from the ME to remit appears to be primarily due to the altruistic motive, whereas the motive of migrants from other destinations to remit is due to both the altruistic and self-interested motives.

The main contribution of this study is to demonstrate that unskilled migrants also play an important role in contributing to source country income. Given the contribution made by unskilled workers to the GDP of these countries, and that the majority of them are temporary migrants, the governments of South Asia should place proper safety nets in place for return migrants. Migrant workers are not documented as a separate category in the South Asia Association for Regional Corporation (SAARC) Charter. Hence there is no obligation by these countries to conform to International Labour Organisation (ILO) labour standards with respect to migrant workers. Low-skilled migrants in 
particular undergo a high social cost when migrating as opposed to those in higher skill categories. These costs include family fragmentation, children taking on household responsibilities in the absence of a parent (Deans, Lonnqvist, and Sen 2006), a wife/husband taking charge of multiple roles in the absence of a husband/wife. This can be emotionally and physically draining leading to adverse health outcomes (Ghosh 2009; Lopez-Ekra et al. 2011). Low-skilled migrants can additionally face exploitation and ill-treatment in host countries, self-sacrifice, and emotional hardship (Datta et al. 2006). Some of the complaints received by migrant workers in Sri Lanka for example include: breach of employment contracts, non-payment of wages, physical and sexual harassment, premature termination of employment (Sri Lanka Bureau of Foreign Employment 2009). These are issues that have not been given sufficient attention to by policy makers or the literature. The focus of the literature has been on skilled migration. Those in the professional categories as opposed to unskilled or low-skilled workers are financially better off in the first instance. Moreover, migration by these groups is more likely to be permanent. ${ }^{10}$ Where migration is not permanent, they are in a position to be accompanied by their families. The social costs incurred by low-skilled workers on the contrary are wide ranging, and not directly measurable as in the case of economic costs and benefits.

Thus, given the high social costs of migration for the low-skilled categories, a question that arises is, whether migration yields a positive net return for these groups. The economic gains of migration and remittances for the low-skilled group may perhaps be completely annulled by the social costs which are much more difficult to measure. Among the reasons put forward to migrate are: poverty, unemployment, the lure of higher wages and networks (IOM 2000). In addition, structural weaknesses in sending countries such as a mismatch between education systems and labour market requirements could also encourage people to migrate. The results suggest that unskilled workers if provided a conducive environment are also able to contribute effectively to home country income. Accordingly, the governments of these economies should take measures to promote rapid economic growth as economic growth would lead to a narrowing of income differentials between home and host countries, and also, low- and high-skilled workers within countries. This would guarantee that migration is voluntary and not forced. Moreover, economic growth could lead to the creation of a productive environment for the promotion of better educational

10 For example, of the total, South Asian migrants residing in the United States, the majority were tertiary qualified. Of the total Bangladeshi, Indian, Pakistani, and Sri Lankan populations in the United States $62 \%, 80 \%, 67 \%$ and $72 \%$ respectively, had tertiary qualifications (Dodani and La Porte 2005). 
opportunities and research and development in source countries for those in the unskilled group permitting them to upgrade their skills. It would also reduce the outflow of those in the professional and skilled categories. India for example has increased the number of graduate technical training schemes provided to skilled graduates in order to retain them (see Wickramasekera 2002a). Investment in training programmes and restructuring education programmes aligned with labour market demand is something that governments should consider. Measures can also be taken to ensure that legislature with respect to minimum wage levels are set and strictly adhered to, for all skill categories. This would ensure that low-skilled and unskilled workers are not exploited.

Migration is not a long-term solution to issues of poverty and unemployment in South Asia. Instability in host countries could lead to a lower demand for migrants increasing the uncertainty and volatility of remittance flows and thus the livelihoods of low-skilled workers. The recent upheaval in the Middle East has demonstrated this. Although migration may offer a short- to medium-term solution to these economies, in the long term, these nations have to pursue effective development policies to promote growth and increase employment opportunities.

\section{Appendix}

Table 8: Description of variables used in the study and data sources

\begin{tabular}{|c|c|}
\hline Series & Source \\
\hline \multirow{6}{*}{$\begin{array}{l}\text { GDP data all countries } \\
\text { Total number of migrants all } \\
\text { countries }\end{array}$} & World Development Indicators (2011) \\
\hline & $\begin{array}{l}\text { Bangladesh: Bureau of Manpower, Employment and Training } \\
\text { (BMET) http://www.bmet.org.bd/BMET/stattisticalDataAction }\end{array}$ \\
\hline & India: Annual reports of the Ministry of Overseas Indian Affairs \\
\hline & Pakistan: Wickramasekara (2002a, 2002b, 2010) \\
\hline & $\begin{array}{l}\text { Sri Lanka: Annual statistical reports Sri Lanka bureau of } \\
\text { foreign employment }\end{array}$ \\
\hline & Nepal: Wickramasekara (2010) \\
\hline \multirow{4}{*}{$\begin{array}{l}\text { Number of migrants to the } \\
\text { Middle East and other } \\
\text { destinations }\end{array}$} & $\begin{array}{l}\text { Bangladesh: Calculated from Bureau of Manpower, } \\
\text { Employment and Training (BMET) }\end{array}$ \\
\hline & $\begin{array}{l}\text { India: Calculated from IOM report 2000, annual reports of the } \\
\text { Ministry of Ovierseas Indian Affairs }\end{array}$ \\
\hline & Pakistan: Calculated from IOM report 2000 , \\
\hline & $\begin{array}{l}\text { Sri Lanka: Calculated from IOM report 2000, annual statistical } \\
\text { reports of the Sri Lanka Bureau of foreign employment. }\end{array}$ \\
\hline
\end{tabular}

(continued) 
Table 8: (Continued)

\begin{tabular}{|c|c|}
\hline Series & Source \\
\hline \multirow[t]{4}{*}{$\begin{array}{l}\text { Number of migrants by skill } \\
\text { level }\end{array}$} & $\begin{array}{l}\text { Bangladesh: Bureau of Manpower, Employment and Training } \\
\text { (BMET) http://www.bmet.org.bd/BMET/stattisticalDataAction }\end{array}$ \\
\hline & $\begin{array}{l}\text { India: Author's own calculation up until } 1998 \text { from Sasikumar } \\
\text { (2001), Khadria (2002) }\end{array}$ \\
\hline & Pakistan: Ahmed, Sugiyarto, and Jha (2010). \\
\hline & $\begin{array}{l}\text { Sri Lanka: Annual statistical reports of the Sri Lanka bureau of } \\
\text { foreign Employment. }\end{array}$ \\
\hline $\begin{array}{l}\text { Total remittances all countries } \\
\text { US } \$\end{array}$ & World Bank (2011): migration and remittance database \\
\hline \multirow{4}{*}{$\begin{array}{l}\text { Remittances from the Middle } \\
\text { East and other destinations } \\
\text { \$US }\end{array}$} & $\begin{array}{l}\text { Bangladesh: Bangladesh Bank (Central Bank of Bangladesh) } \\
\text { http://www.bangladesh-bank.org }\end{array}$ \\
\hline & India: Reserve Bank of India Bulletins \\
\hline & $\begin{array}{l}\text { Pakistan: Pakistan Bureau of Employment and Overseas } \\
\text { Employment http://www.beoe.gov.pk/Remittance.asp, State } \\
\text { Bank of Pakistan Economic Data http://www.sbp.org.pk/ } \\
\text { ecodata/index2.asp }\end{array}$ \\
\hline & $\begin{array}{l}\text { Sri Lanka: annual statistical reports of the Sri Lanka bureau of } \\
\text { foreign employment }\end{array}$ \\
\hline Labour force all countries & World Development Indicators (2011) \\
\hline$M 2$ & World Development Indicators (2011) \\
\hline $\begin{array}{l}\text { Secondary enrolment ratio all } \\
\text { countries }\end{array}$ & World Development Indicators (2011) \\
\hline Openness all countries & World Development Indicators (2011) \\
\hline Capital stock all countries & Authors own calculation \\
\hline Inflation rate CPI (\% annual) & World Development Indicators (2011) \\
\hline Deposit rate (\% annual) & World Development Indicators (2011) \\
\hline $\begin{array}{l}\text { Official exchange rate: local } \\
\text { currency per US\$ }\end{array}$ & World Devèlopment Indicators (2011) \\
\hline
\end{tabular}

Notes: The capital stock is estimated using the perpetual inventory method. The initial capital stock KO for each country is estimated as (see Krüger 2003): $K_{0}=I_{0}\left(\frac{1+g}{g+\rho}\right)$ Where $I_{0}$ is the amount of investment in the first period, $g$ is the average rate of growth of investment over the subsequent 5 years and $\rho=0.1$ (a depreciation rate of $10 \%$ ). The capital stocks of the subsequent years are calculated according to the equation: $K_{t}=(1-\rho) K_{t-1}+I_{t}$ 


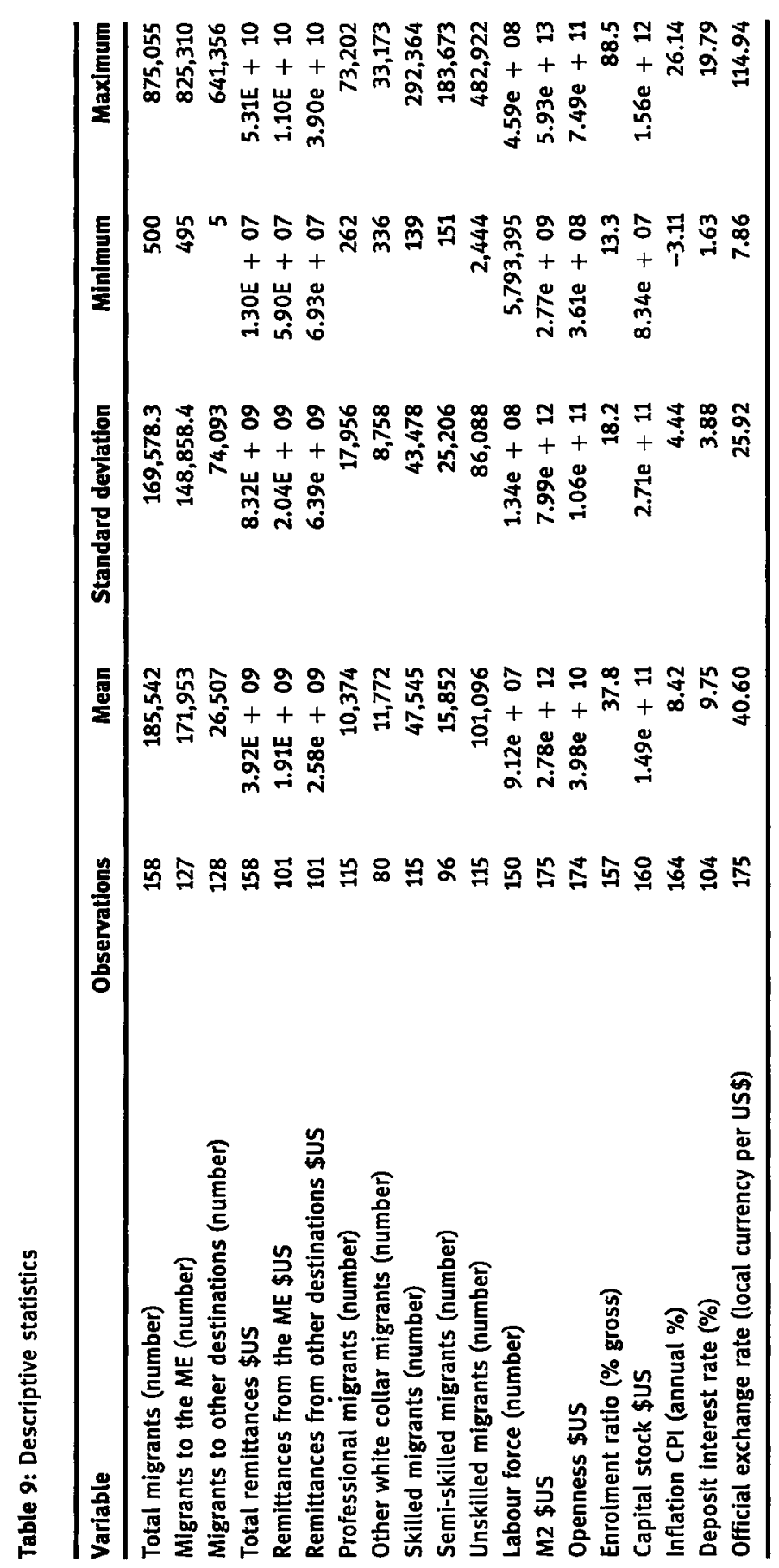

Srought to you by | Michigan State University Authenticated | 10.248.254.158 


\section{References}

Acosta, P., C. Calderon, P. Fajnzylber, and H. Lopez. 2008. "What Is the Impact of International Remittances on Poverty and Inequality in Latin America?" World Development 36:89-114.

Adams, R. 2001. "The Economic Impact and Uses of International Remittances in Rural Egypt." Economic Development and Cultural Change 39:698-722.

Adams, R. 2002. "Precautionary Saving from Different Sources of Income: Evidence from Rural Pakistan." World Bank Policy Research Working Paper 2761, Washington, DC.

Adams, R., and J. Page. 2003. "Poverty, Inequality and Growth in Selected Middle East and North Africa Countries, 1980-2000." World Development 31:2027-48.

Adams, R., and J. Page. 2005. "Do International Migration and Remittances Reduce Poverty in Developing Countries?" World Development 33:1645-69.

Adelman, I., and I. E. Taylor. 1990. "Is Structural Adjustment with a Human Face Possible? The Case of Mexico." Journal of Development Studies 26:387-407.

Aggarwal, R., A. Demirguc-Kunt, and M. Martinez-Peria. 2006. 'Do Workers' Remittances Promote Financial Development?" World Bank Policy Research Working Paper 3957, Washington, DC.

Ahmed, V., G. Sugiyarto, and S. Jha. 2010. “Remittances and Household Welfare: A Case Study of Pakistan." ADB Economics Working Paper Series No. 194, Manila.

Arunatilake, N., P. Jayawardena, and D. Weerakoon. 2011. "Sri Lanka." In Migration, Remittances and Development in South Asia, edited by S. Kelegama. New Delhi: Sage.

Banerjee, B. 1984. "The Probability, Size and Uses of Remittances from Urban to Rural Areas in India." Journal of Development Economics 16:293-311.

Bangladesh Bank. 2011. Accessed November 2011. http://www.bangladesh-bank.org.

Beine, M., F. Docquier, and H. Rapoport. 2008. "Brain Drain and Human Capital Formation in Developing Countries: Winners and Losers." The Economic Journal 118:631-52.

Bureau of Manpower, Employment and Training. 2011. "Bangladesh." Accessed November 2011. http://www.bmet.org.bd/BMET/stattisticalDataAction.

Chami, R., D. Hakura, and P. Montiel. 2009. “Remittances: An Automatic Output Stabilizer?” IMF Working Papers 91/2009, International Monetary Fund.

Coombes, J., and C. Ebeke. 2011. "Remittance and Household Consumption Instability in Developing Countries." World Development 39:1076-89.

Datta, K., C. Mcllwaine, J. Wills, Y. Evans, J. Herbert, and J. May. 2006. "Challenging Remittances as the New Development Mantra: Perspectives from Low-Paid Migrant Workers in London." Accessed November 2011. http://www.geog.qmul.ac.uk/globalcities/ reports/docs/remittances.pdf.

Deans, F., L. Lonnqvist, and K. Sen. 2006. "Remittances and Migration: Some Policy Considerations for NGOs." INTRAC Policy Briefing Paper No. 8, INTRAC-NGO Research Programme.

Devadoss, S., and J. Foltz. 1996. “Evaluation of Factors Influencing Student Class Attendance and Performance." American Journal of Agricultural Economics 78:499-507.

de Haas, H. 2007. "Remittances, Migration and Social Development: A Conceptual Review of the Literature." United Research Institute for Social Development, Social Policy and Development Programme Paper No. 34, Geneva.

Docquier, F., and A. Marfouk. 2005. "International Migration by Educational Attainment 19902000 (Release 1).” Accessed November 2011. http://perso.uclouvain.be/frederic.docquier/ filePDF/DM_ozdenschiff.pdf. 
Docquier, F., O. Lohest, and A. Marfouk. 2007. "Brain Drain in Developing Regions (1999-2000)." World Bank Development Review 21:193-218.

Docquier, F., B. L. Lowell, and A. Marfouk. 2009. "A Gendered Assessment of the Brain Drain." Population and Development Review 35:297-321.

Dodani, S., and R. La Porte. 2005. "Brain Drain from Developing Countries: How Can Brain Drain Be Converted into Wisdom Gain?" Journal of the Royal Society if Medicine 98:487-91.

Elbadawi, I., and R. Rocha. 1992. "Determinants of Expatriate Workers' Remittances in North Africa and Europe." World Bank Working Paper No. 1038, Washington, DC.

Faini, R. 2007. "Remittances and the Brain Drain: Do More Skilled Migrants Remit More?" World Bank Economic Review 21:177-91.

Ghosh, J. 2009. "Migration and Gender Empowerment: Recent Trends and Emerging Issues." Human Development Research Paper, No. 4, United Nations Development, New York.

Giuliano, P., and M. Ruiz-Arranz. 2009. "Remittances, Financial Development and Growth." Journal of Development Economics 90:144-52.

Glytos, N. 1997. "Remitting Behaviour of 'Temporary' and 'Permanent' Migrants: The Case of Greeks in Germany and Australia." Labour 11:409-35.

Hoddinott, J. 1994. "A Model of Migration and Remittances Applied to Western Kenya." Oxford Economic Papers 46:459-76.

IOM. 2000. World Migration Report. Geneva: IOM and United Nations.

Katseli, L. T., and N. P. Glytsos. 1989. "Theoretical and Empirical Determinants of International Labour Mobility: A Greek-German Perspective." In European Factor Mobility: Trends and Consequences, edited by I. Gordon and A. P. Thirlwall, 95-115. London: Macmillan Press.

Khadria, B. 2002. "Skilled Labour Migration from Developing Countries: Study on India." International Migration Papers 49, International Migration Programme, ILO, Geneva.

Khatri, S. 2007. "Labour Migration, Employment and Poverty Alleviation in South Asia." Proceedings of the Regional Seminar jointly organized by South Asia Centre for Policy Studies (SACEPS) and Friedrich Ebert Stiftung (FES), Kathmandu, Nepal.

Kim, S. 1986. "Labour Migration from Korea to the Middle East: It's Trends and Impact on the Korean Economy." In Asian Labour Migrations: Pipeline to the Middle East, edited by F. Arnold and N. M. Shah, 163-76. Boulder, CO: Westview.

Koc, I., and I. Onan. 2004. "International Migrants' Remittances and Welfare Status of the Left Behind Families in Turkey." International Migration Review 38:78-112.

Krüger, J.J. (2003), "The global trends of total factor productivity: evidence from the nonparametric Malmquist index approach." Oxford Economic Papers 55:265-286.

Lianos, T. 1997. “Factors Determining Migrant Remittances: The Case of Greece." International Migration Review 31:72-87.

Lopez-Ekra, S., C. Aghazarm, H. Kotter, and B. Mollard. 2011. "The Impact of Remittances on Gender Roles and Opportunities for Children in Recipient Families: Research from the International Organization for Migration." Gender and Development 19:69-80.

Lucas, R., and 0. Stark. 1985. "Motivations to Remit: Evidence from Botswana." Journal of Political Economy 93:901-18.

Lueth, E., and M. Ruiz-Arranz. 2008. "Determinants of Bilateral Remittance Flows." The B.E Journal of Macroeconomics 8:Article 26.

Martin, P., S. Martin, and P. Weil. 2002. "Best Practice Options: Mali." International Migration 40:87-99.

Ministry of Overseas Indian Affairs. (1976-2010). "Annual Reports," Various Issues, India. 
Mundaca, B. G. 2009. "Remittances, Financial Market Development, and Economic Growth: The Case of Latin America and the Caribbean." Review of Development Economics 13:288-303.

Niimi, Y., C. Ozden, and M. Schiff. 2010. "Remittances and the Brain Drain: Skilled Migrants Do Remit Less." Annals of Economics and Statistics 97/98:123-41.

Orozco, M. 2000. "Latino Hometown Associations as Agents of Development in Latin America." Inter-American Dialogue Research Series, June, Washington, DC.

Pakistan Bureau of Employment and Overseas Employment. 2011. Accessed November 2011. http://www.beoe.gov.pk/Remittance.asp.

Ratha, D., S. Mohapatra, and A. Silwal. 2010. "Outlook for Remittance Flows 2010-11, Migration and Development Brief 12." Migration and Remittance Team Development Prospects Group, World Bank.

Ratha, D., S. Mohapatra, and A. Silwal. 2011. "The Migration and Remittances Factbook." Migration and Remittances Unit, World Bank.

Reserve Bank of India Bulletins. (1976-2010). Various issues, India.

Rosenzweig, M. R. 1988. "Risk, Implicit Contracts and the Family in Rural Areas of Low-Income Countries." Economic Journal 98:1148-70.

Rozelle, S., J. E. Taylor, and A. deBrauw. 1999. “Migration, Remittances and Agricultural Productivity in China." American Economic Review 89:287-91.

Sasikumar, S. K. 2001. "Interantional Labour Migration from Independent India." Accessed November 2011. http://www.indialabourarchives.org/publications/sksasikumar.htm.

Sri Lanka Bureau of Foreign Employment Annual Statistical Reports. 2009. Various issues, Sri Lanka.

Stark, 0., and D. Lehvari. 1982. "On Migration and Risk in LDC5." Economic Development and Cultural Change 3:191-6.

State Bank of Pakistan. 2011. "Economic Data." Accessed November 2011. http://www.sbp.org. pk/ecodata/index2.asp.

Swamy, G. 1981. "International Migrant Workers' Remittances: Issues and Prospects." World Bank Working Paper No. 481, Washington, DC.

Taylor, J. E. 1999. "The New Economics of Labor Migration and the Role of Remittances." International Migration 37:63-86.

Taylor, J. E., J. Mora, R. Adams, and A. Lopez-Feldman. 2005. "Remittances, Inequality and Poverty: Evidence from Rural Mexico." Working Paper No. 05-003. Department of Agricultural and Resource Economics, University of California, Davis, CA.

Wickramasekara, P. 2002a. "Asian Labour Migration: Issues and Challenges in an Era of Globalisation." International Migration Papers No. 57e, International Labour Office, Geneva.

Wickramasekera, P. 2002b. "Perspectives on Labour Migration." Social Protection Sector, International Migration Programme Paper 5E, International Labour Office, Geneva.

Wickramasekara, P. 2010. "Labour Migration in South Asia: A Review of Issues, Policies and Practices." International Migration Papers No. 108, International Labour Office, Geneva.

World Bank. 2011. World development indicators. Washington, DC: World Bank.

Yang, D., and H. Choi. 2007. "Are Remittances Insurance? Evidence from Rainfall Shocks in the Philippines." World Bank Economic Review 21:219-48. 